\title{
A rapid and accurate new bedside test to assess maximal liver function: a case report
}

\author{
Sascha A Müller ${ }^{1,3^{*}}$, Ignazio Tarantino ${ }^{1}$, Marcello Corazza ${ }^{1}$, Frank Pianka ${ }^{1}$, Jürgen Fornaro², Ulrich Beutner ${ }^{1}$, \\ Cornelia Lüthi ${ }^{1}$ and Bruno M Schmied ${ }^{1}$
}

\begin{abstract}
Background: In liver surgery, appropriate preoperative evaluation and preparation of the patient is of cardinal importance. The up-to-date, preoperative prediction of residual liver function has thus far been limited. As posthepatectomy liver failure is a major cause of mortality, a new and simple bedside test (LiMAx) has been developed to predict postoperative liver function in conjunction with preoperative volumetric analysis of the liver.

Case presentation: A 45-year-old patient presented with a cecal carcinoma and a large synchronous liver metastasis for major liver surgery. Liver function was determined by the LiMAx-test for the enzymatic capacity of cytochrome P450 1A2, which is ubiquitously and solely active in the liver. A solution of $2 \mathrm{mg} / \mathrm{kg}$ body weight ${ }^{13} \mathrm{C}$-labeled methacetin was injected as a bolus into an intravenous catheter and, thereafter, was metabolized into acetaminophen and ${ }^{13} \mathrm{CO} 2$ and pulmonarily exhaled. The analysis of the ${ }^{13} \mathrm{CO} 2 /{ }^{12} \mathrm{CO} 2$ ratio was performed using online breath sampling over a period of maximally 60 minutes. Based on this test, a value of more than $315 \mu \mathrm{g} / \mathrm{kg} / \mathrm{h}$ represents normal liver function. A laparoscopic right hemihepatectomy was planned during virtual resection with a residual liver volume of $48 \%$ and a preoperative anticipated residual LiMAx of $301 \mu \mathrm{g} / \mathrm{kg} / \mathrm{h}$. After successful resection, the initial postoperative LiMAx value was $316 \mu \mathrm{g} / \mathrm{kg} / \mathrm{h}$, indicating good liver function and a correct prediction of the outcome.
\end{abstract}

Conclusion: In the presented patient, residual liver function could be accurately predicted preoperatively using a combination of the new LiMax test with CT-volumetry. This test might significantly improve preoperative evaluation and postoperative outcomes in liver surgery.

Keywords: Liver function, Liver volumetry, Liver resection, Liver function measurement, LiMAx

\section{Background}

Improvements in surgical techniques, anesthetic protocols, and perioperative care have decreased morbidity and mortality and have contributed to an increase in extended liver resections. This more aggressive approach inevitably leads to smaller remnant livers with a substantially elevated risk of post-resectional liver failure (PLF) [1-3]. It was demonstrated that $80 \%$ of deaths caused by PLF occur after resecting more than $50 \%$ of the liver volume [4-6], and the PLF incidence increases with the number of resected segments [5]. Therefore, accurate preoperative volumetric calculation of total and partial liver volumes based on preoperative imaging and

\footnotetext{
* Correspondence: Sascha.mueller@kssg.ch

${ }^{1}$ Department of Surgery, Kantonsspital St.Gallen, St.Gallen, Switzerland

${ }^{3}$ Rorschacherstrasse 95, 9007 St.Gallen, Switzerland

Full list of author information is available at the end of the article
}

resection planning is crucial in the assessment of hepatic functional reserve and resectability, especially in cases of major liver resection and patients with underlying parenchymal disease [7]. Liver steatosis and steatohepatitis, for example, are associated with an increased risk of PLF after partial liver resection, especially after neoadjuvant chemotherapy, or in living donor liver transplantation [8]. Traditional methods estimating the hepatic functional reserve, such as liver enzyme tests and ChildPugh classification, have clinical and practical limitations [9]. The major disadvantage of most quantitative liver function tests, such as the indocyanine green clearance test and the galactose elimination capacity, is that they are influenced by several factors such as hepatic blood flow and hyperbilirubinemia [10]. Moreover, no reliable cutoffs and guidelines could be defined. Consequently, clinical decisions mainly rely on the surgeon's experience [1].

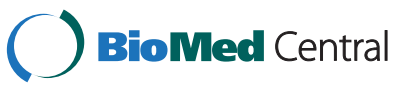


Until now no biological marker or score has been able to reliably measure total liver function or predict the postoperative outcome. Here, we present the LiMAx-test, which has been developed at the Department of General, Visceral and Transplantation Surgery at the Charité in Berlin [11]. The test has been successfully evaluated in many patients undergoing liver surgery and liver transplantation since 2003 [11,12]. This test is now used in all patients with planned liver resection in our surgical department and in several other European centers.

\section{The new LiMAx-test}

This breath test is based on the hepatocyte-specific metabolism of the cytochrome P450 1A2 enzyme, which is active throughout the liver. After 3 hours of fasting, patients are placed in a resting horizontal position. The activity of the enzyme is measured by i.v. bolus injection of non-radioactive ${ }^{13} \mathrm{C}$-methacetin $(2 \mathrm{mg} / \mathrm{kg}$ body weight). Ten minutes prior to the injection with ${ }^{13} \mathrm{C}$-methacetin, the baseline ${ }^{13} \mathrm{CO}_{2} /{ }^{12} \mathrm{CO}_{2}$ ratio is recorded. ${ }^{13} \mathrm{C}$-methacetin (Euriso-top, Saint-Aubin, Cedex, France) is metabolized into acetaminophen and ${ }^{13} \mathrm{CO}_{2}$, which is pulmonarily exhaled. The exhaled air is collected using a face mask (Humedics $\mathrm{GmbH}$, Berlin Germany), and the ${ }^{13} \mathrm{CO}_{2} /{ }^{12} \mathrm{CO}_{2}$ ratio in the air is determined using a modified nondispersive isotope-selective infrared spectroscopy (FANci2-db16, Fischer Analysen Instumente, Leipzig, Germany, Humedics $\mathrm{GmbH}$, Berlin, Germany) [11,13]. Based on the ${ }^{13} \mathrm{CO}_{2} /{ }^{12} \mathrm{CO}_{2}$ ratio and the body weight, the cytochrome P450 1A2 activity is determined using the so-called LiMAx value with the unit $\mu \mathrm{g} / \mathrm{kg} / \mathrm{h}$ ( $\mu \mathrm{g}$ methacetin $/ \mathrm{kg}$ body weight/hour). The analysis of the ${ }^{13} \mathrm{CO} 2 /{ }^{12} \mathrm{CO} 2$ ratio is performed over a period of 20 to 60 minutes. For normal liver function, a LiMAx value over $315 \mu \mathrm{g} / \mathrm{kg} / \mathrm{h}$ is required. In healthy volunteers, the normal range of LiMAx was found to be $425 \pm 67 \mu \mathrm{g} / \mathrm{kg} / \mathrm{h}$ (range 311-575 $\mu \mathrm{g} / \mathrm{kg} / \mathrm{h}$ ). Furthermore, the correlation between repeated measurements was found to be 0.82 [11].

\section{Case report}

A 45-year-old patient in good general health presented with a cecal carcinoma and a large synchronous liver metastasis. After neo-adjuvant chemotherapeutic treatment with 5-FU, Irinotecan and Oxaliplatin, a "liver first" approach was decided by the tumor board. The preoperative LiMAx value was $622 \mu \mathrm{g} / \mathrm{kg} / \mathrm{h}$, functional liver volume was $1736 \mathrm{~mL}$, and tumor volume was $351 \mathrm{~mL}$. A laparoscopic left hemihepatectomy was planned during virtual resection with a functional resection of $895 \mathrm{~mL}$, resulting in a residual liver volume of $841 \mathrm{~mL}(48 \%)$ and a pre-operatively anticipated residual LiMAx of $301 \mu \mathrm{g} / \mathrm{kg} / \mathrm{h}$ (Figure 1). The laparoscopic left hemihepatectomy was performed under general anesthesia in the supine position using 5 ports according to the technique described by

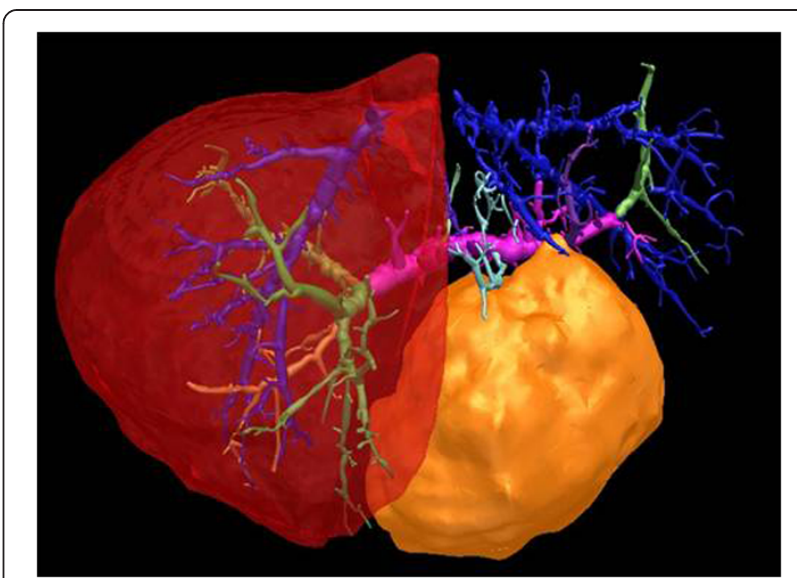

Figure 1 Three-dimensional computation from a preoperative CT scan of the patient with a large liver metastasis (superior view). The portal vein is pink and green, the hepatic veins are blue, and the tumor is yellow.

Pearce et al. [14]. Briefly after applying a nylon tape around the portal triad for the Pringle maneuver, the liver was completely mobilized. The resection plane was defined by intraoperative ultrasound. After vascular control, the dissection was performed by harmonic scalpel (Harmonic ACE; Ethicon Endo-Surgery, Cincinnati, OH, USA) and Cavitron Ultrasonic Surgical Aspirator (Valleylab, Boulder, CO, USA) under intermittent Pringle maneuver. After completion of adequate hemostasis, the specimen was removed in an impermeable bag (Endocatch; Ethicon EndoSurgery) introduced through a $15-\mathrm{mm}$ suprapubic port subsequently extended through a Pfannenstiel incision. The operation time was 5.5 hours, and the intraoperative blood loss was $300 \mathrm{~mL}$.

After successful resection, the initial postoperative LiMAx value on postoperative day one was $316 \mu \mathrm{g} / \mathrm{kg} / \mathrm{h}$, indicating good liver function and correct prediction of the outcome. After an uneventful postoperative course, the patient was discharged on postoperative day six. Eight days later, an uneventful laparoscopic right hemicolectomy was performed to remove the primary tumor.

\section{Discussion}

As impressively demonstrated by the presented case, the LiMAx-test in combination with a CT-based liver volumetry can reliably predict the postoperative liver function. Therefore, we adopted these preoperative tests as a standard procedure for every patient undergoing liver resection at our institution.

In 2010, Stockmann et al. published the LiMAx algorithm, which is an easily applicable clinical decision tree for preoperative resection planning [15]. This allows 
effective preoperative surgical risk evaluation to prevent major complications or even liver failure-related death. Normal liver function (LiMAx $>315 \mu \mathrm{g} / \mathrm{kg} / \mathrm{h}$ ) allows the resection of up to four liver segments without further consideration. By contrast, patients with strongly impaired liver function (LiMAx $<140 \mu \mathrm{g} / \mathrm{kg} / \mathrm{h}$, indicating significant hepatic injury) are not eligible for surgery as they are prone to developing postoperative liver failure even after minor liver resection. Patients with limited hepatic impairment and a preoperative LiMAx-value between $140-315 \mu \mathrm{g} / \mathrm{kg} / \mathrm{h}$ are the most challenging ones. In these patients, precise liver volumetry is mandatory for a planned major liver resection (>four liver segments). Resections with an expected residual LiMAx value less than $80 \mu \mathrm{g} / \mathrm{kg} / \mathrm{h}$ should be avoided because they are associated with a high mortality of up to $40 \%$. Planned resections with a predicted residual LiMAx value between $80-100 \mu \mathrm{g} / \mathrm{kg} / \mathrm{h}$ are considered critical (10.5\% postoperative mortality), and thus alternative therapies or additional preoperative procedures should be considered (i.e., portal vein embolization, neo-adjuvant chemotherapy to downstage tumors). Liver resections with expected residual LiMAx values of $>100 \mu \mathrm{g} / \mathrm{kg} / \mathrm{h}$ can safely be performed.

The LiMAx test can clearly help to avoid postresectional liver failure. Thus, one could expect a relevant impact on health care costs. Recently, Lock et al. published a study examining 45 patients after major liver resection [16]. Eight patients developed postoperative liver failure, seven of these died in the postoperative course. Patients developing post-resectional liver failure generated higher costs than patients without postresectional liver failure $(82,199 €[95 \% \mathrm{CI}: 42,812-$ $21,586 €]$ vs. $25,980 €[95 \% \mathrm{CI}: 9,559-42,401 €] ; \mathrm{p}=0.013$ ) [14]. The proportion of intensive-care unit cost relative to total costs increased from $30 \%$ to more than $50 \%$, and the cost for blood tests and products from the blood bank increased more than eightfold from $819 €$ [95\%CI: 0 $1,837 €]$ to $6,953 €[95 \% \mathrm{CI}: 4,512-9,395 €] ; \mathrm{p} \leq 0.001$ ). In covariate analysis, overall costs related to postresectional liver failure were $56,219 €[95 \% \mathrm{CI}$ : 12,327 $100,066 €]$. Routinely applying the LiMAx test, we can achieve an optimized and individualized treatment for patients scheduled for liver resections. This ultimately leads to economic savings by significantly decreasing morbidity and mortality and the overall length of hospital stay.

\section{Conclusion}

In the presented patient, residual liver function could be accurately predicted preoperatively by the combination of the new LiMax test with CT-volumetry. Considering the existing literature, the LiMAx test significantly improves preoperative evaluation and postoperative outcomes in liver surgery.

\section{Consent}

Written informed consent was obtained from the patient for the publication of this case report.

\section{Competing interests}

The authors declare no conflicts of interest. In particular, the authors do not have any specific conflict of interest related to the manufacturer of the LiMAx test, including intellectual property, patents or patents pending, industrial relation to the manufacturer, or speaker's honoraria.

\section{Authors' contributions}

Data were prepared and reviewed by SAM, MC, CL and FP. JF reviewed radiological images. The manuscript was drafted by SAM, IT and UB and critically edited by BMS. All authors read and approved the final manuscript.

\section{Author details}

${ }^{1}$ Department of Surgery, Kantonsspital St.Gallen, St.Gallen, Switzerland.

${ }^{2}$ Institute of Radiology, Kantonsspital St.Gallen, St.Gallen, Switzerland.

${ }^{3}$ Rorschacherstrasse 95, 9007 St.Gallen, Switzerland.

Received: 13 February 2013 Accepted: 17 April 2013

Published: 25 April 2013

\section{References}

1. Schneider PD: Preoperative assessment of liver function. Surg Clin North Am 2004, 84(2):355-373.

2. Belghiti J, Hiramatsu K, Benoist S, Massault P, Sauvanet A, Farges O: Seven hundred forty-seven hepatectomies in the 1990s: an update to evaluate the actual risk of liver resection. J Am Coll Surg 2000, 191(1):38-46.

3. Clavien P-A, Petrowsky H, DeOliveira ML, Graf R: Strategies for safer liver surgery and partial liver transplantation. N Engl J Med 2007, 356(15):1545-1559.

4. Poon RT, Fan ST, Lo CM, Liu CL, Lam CM, Yuen WK, Yeung C, Wong J: Improving perioperative outcome expands the role of hepatectomy in management of benign and malignant hepatobiliary diseases: analysis of 1222 consecutive patients from a prospective database. Ann Surg 2004, 240(4):698-708.

5. Schindl MJ, Redhead DN, Fearon KCH, Garden OJ, Wigmore SJ: The value of residual liver volume as a predictor of hepatic dysfunction and infection after major liver resection. Gut 2005, 54(2):289-296.

6. Hammond JS, Guha IN, Beckingham IJ, Lobo DN: Prediction, prevention and management of postresection liver failure. Br J Surg 2011, 98(9):1188-1200.

7. Pianka F, Baumhauer M, Stein D, Radeleff B, Schmied BM, Meinzer H-P, Müller SA: Liver tissue sparing resection using a novel planning tool. Langenbecks Arch Surg 2011, 396(2):201-208.

8. Veteläinen R, van Vliet A, Gouma DJ, van Gulik TM: Steatosis as a risk factor in liver surgery. Ann Surg 2007, 245(1):20-30.

9. Mullin EJ, Metcalfe MS, Maddern GJ: How much liver resection is too much? Am J Surg 2005, 190(1):87-97.

10. Stehr A, Ploner F, Traeger K, Theisen M, Zuelke C, Radermacher P, Matejovic $\mathrm{M}$ : Plasma disappearance of indocyanine green: a marker for excretory liver function? Intensive Care Med 2005, 31(12):1719-1722.

11. Stockmann M, Lock JF, Riecke B, Heyne K, Martus P, Fricke M, Lehmann S, Niehues SM, Schwabe M, Lemke AJ, Neuhaus P: Prediction of postoperative outcome after hepatectomy with a new bedside test for maximal liver function capacity. Ann Surg 2009, 250(1):119-125.

12. Lock JF, Schwabauer E, Martus P, Videv N, Pratschke J, Malinowski M, Neuhaus $P$, Stockmann M: Early diagnosis of primary nonfunction and indication for reoperation after liver transplantation. Liver Transp/ 2010, 16(2):172-180

13. Riecke $B$, Neuhaus $P$, Stockmann M: Major influence of oxygen supply on ${ }^{13} \mathrm{CO}_{2}:{ }^{12} \mathrm{CO}$ ratio measurement by nondispersive isotope-selective infrared spectroscopy. Helicobacter 2005, 10(6):620-622.

14. Pearce NW, Di Fabio F, Teng MJ, Syed S, Primrose JN, Abu Hilal M: Laparoscopic right hepatectomy: a challenging, but feasible, safe and efficient procedure. Am J Surg 2011, 202(5):e52-e58. 
15. Stockmann M, Lock JF, Malinowski M, Niehues SM, Seehofer D, Neuhaus P: The LiMAx test: a new liver function test for predicting postoperative outcome in liver surgery. HPB (Oxford) 2010, 12(2):139-146.

16. Lock JF, Reinhold T, Malinowski M, Pratschke J, Neuhaus P, Stockmann M: The costs of postoperative liver failure and the economic impact of liver function capacity after extended liver resection-a single-center experience. Langenbecks Arch Surg 2009, 394(6):1047-1056.

doi:10.1186/1754-9493-7-11

Cite this article as: Müller et al:: A rapid and accurate new bedside test to assess maximal liver function: a case report. Patient Safety in Surgery 2013 7:11.

\section{Submit your next manuscript to BioMed Central and take full advantage of:}

- Convenient online submission

- Thorough peer review

- No space constraints or color figure charges

- Immediate publication on acceptance

- Inclusion in PubMed, CAS, Scopus and Google Scholar

- Research which is freely available for redistribution 